\title{
Jatroidaine A: a New Tetranortirucallane Type Triterpene from
}

\section{Jatropha multifida}

\author{
Fei Li ${ }^{1}$, Liang Ma ${ }^{1}$, Jinyuan Zhang ${ }^{1}$, Xueling, Qiao ${ }^{1}$, \\ Dingshan Zhang ${ }^{2}$ and Dongbo Zhang ${ }^{2 *}$
}

\author{
${ }^{I}$ Shaanxi University of Chinese Medicine, Xianyang 712046, P. R. China \\ ${ }^{2}$ Co-construction Collaborative Innovation Center for Chinese Medicine Resources Industrialization \\ by Shaanxi \& Education Ministry, State Key Laboratory of Research \& Development of Characteristic \\ Qin Medicine Resources (Cultivation), Shaanxi Innovative Drug Research Center, Shaanxi University \\ of Chinese Medicine, Xianyang 712046, P. R. China
}

(Received February 18, 2021; Revised March 21, 2021; Accepted March 22, 2021)

\begin{abstract}
Jatroidaine A (1), a new tetranortirucallane-type triterpene, and two known analogues (2-3) were isolated from the leaves and branches of Jatropha multifida. Their structures were fully elucidated by extensive spectroscopic methods and comparison to known compounds. The absolute configuration of $\mathbf{1}$ was assigned by single-crystal X-ray diffraction analysis. All compounds were evaluated for their anti-inflammatory and thioredoxin reductase (TrxR) inhibitory activities. Unfortunately, no significant activity was observed.
\end{abstract}

Keywords: Jatropha multifida; tirucallane triterpene; anti-inflammatory activity; thioredoxin reductase.

() 2021 ACG Publications. All rights reserved.

\section{Introduction}

Jatropha multifida (Euphorbiaceae), commonly called "Shan-Hu-Hua" in China, is a multipurpose shrub widely cultivated as an ornamental plant in South America and South China [1], and its roots, stems, leaves, and seeds have been traditionally used to treat oral candidiasis, gonorrhoea, fever, astriction, wounds and skin infections in African folk medicine [2-4]. Investigation on $J$. multifida showed that this plant was a rich source of structurally attractive diterpenoids with diverse biological activities including cytotoxic, antibacterial, antileishmanial, antimalarial, antiviral, larvicidal, and thioredoxin reductase inhibitory (TrxR) effects [1, 5-8]. However, no previous studies on triterpenoids have been reported from the plant. In continuation of our work on the Jatropha species [9-10], a new tetranortirucallane-type triterpene, jatroidaine A (1), and two known analogues (2-3) (Figure 1) were isolated from J. multifida. Herein, the isolation, structural elucidation, and the anti-inflammatory and TrxR inhibitory effects of these isolates are described.

\footnotetext{
*Corresponding author: E-Mail: symensu@163.com
} 


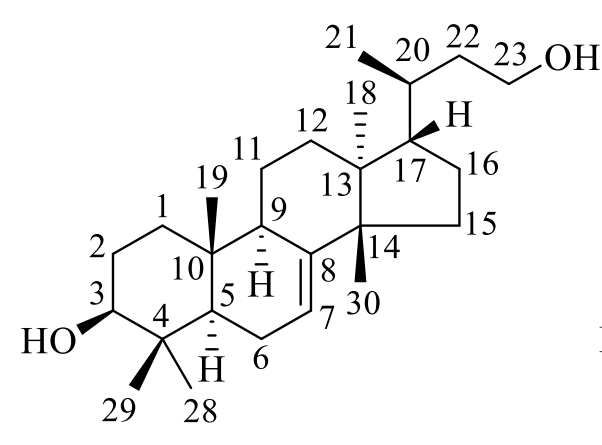

1

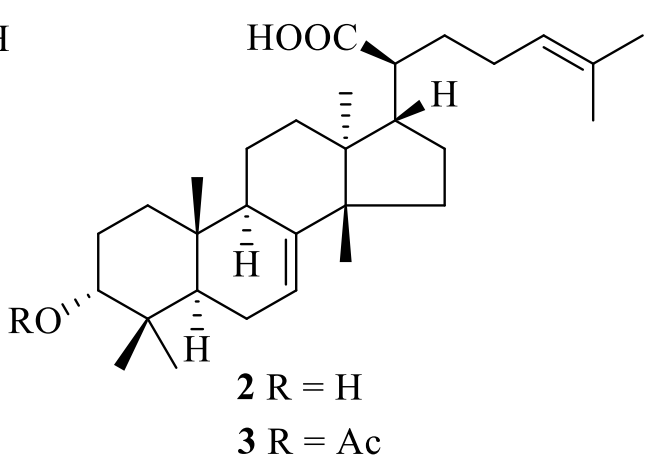

$3 \mathrm{R}=\mathrm{Ac}$

Figure 1. Structures of compounds $1-3$

\section{Materials and Methods}

\subsection{Plant Material}

The leaves and branches of $J$. multifida were gathered from Mengla County, Yunnan Province, P. R. China, in July 2019 and identified by Associate Professor Daogeng Yu, Chinese Academy of Tropical Agricultural Science, Danzhou, P. R. China. A voucher specimen (No. 20190711) was deposited at the Natural Product Laboratory of Shaanxi Collaborative Innovation Center of Chinese Medicinal Resource Industrialization, Shaanxi University of Chinese Medicine.

\subsection{General Experimental Procedures}

NMR spectra were recorded on a Bruker Avance III-600 spectrometer. X-ray diffraction experiment was collected on a Bruker APEX-II CCD diffractometer with $\mathrm{Cu} \mathrm{K} \alpha$ radiation. Melting point was measured on a X-4 microscopic melting point meter. Infrared spectrum was recorded on a Bruker Tensor II spectrometer with an ATR sensor. HRESIMS data was measured on a Bruker APEX II mass spectrometer. Column chromatography (CC) was performed on silica gel (Shanghai Titan Scientific Co., Ltd, Shanghai, China), Sephadex LH-20 (St. Louis, MO, USA), and ODS (Mitsubishi Chemical Industries, Tokyo, Japan). Fractions were monitored by TLC and spots were visualized by sprayed with $5 \% \mathrm{H}_{2} \mathrm{SO}_{4}$ in EtOH followed by heating.

\subsection{Extraction and Isolation}

The fresh leaves and branches of J. multifida $(1.0 \mathrm{~kg})$ were cut and extracted with $70 \% \mathrm{MeOH}(5$ $\times 3 \mathrm{~L}, 2 \mathrm{~h}$ each) under reflux to give $38.0 \mathrm{~g}$ of crude extract. The extract was suspended in $\mathrm{H}_{2} \mathrm{O}$ and partitioned with EtOAc $(1.0 \mathrm{~L} \times 3)$. The EtOAc extract $(10.2 \mathrm{~g})$ was subjected to ODS gel medium pressure liquid chromatography with $\mathrm{H}_{2} \mathrm{O}-\mathrm{MeOH}(1: 0-0: 1)$ to afford fractions $1-10$. Fraction $8(0.5 \mathrm{~g})$ was chromatographed on a silica gel CC eluted with petroleum ether/EtOAc (10:1) to obtain compound $1(1.7 \mathrm{mg})$. Fraction 6 (1.3 g) was separated by performing Sephadex LH-20 CC eluted with $\mathrm{MeOH}$ to afford subfractions 6.1-6.8. Subfraction $6.3(0.19 \mathrm{~g})$ was purified by a silica gel CC eluted with petroleum ether/acetone (2:1) to yield compounds 2 (3.1 $\mathrm{mg}$ ) and $\mathbf{3}(1.9 \mathrm{mg})$.

\subsection{Crystal Data of 1}

Crystallographic Data for $\mathbf{1}$ was collected on a Bruker APEX-II CCD diffractometer with $\mathrm{Cu} \mathrm{K} \alpha$ radiation $(\lambda=1.54178 \AA)$ and refined with the SHELXL refinement package using Least Squares minimisation. The crystallographic data have been deposited at the Cambridge Crystallographic Data Centre as CCDC 2042110 for 1. Crystal Data: $\mathrm{C}_{26} \mathrm{H}_{44} \mathrm{O}_{2}(M=388.61 \mathrm{~g} / \mathrm{mol})$ : triclinic, space group $P 1\left(\right.$ no.1) $, a=10.9288(3) \AA, b=11.7408(4) \AA, c=15.7438(5) \AA, \alpha=84.345(2)^{\circ}, \beta=69.749(2)^{\circ}, \gamma=$ 66.639(2) ${ }^{\circ}, V=1738.14(10) \AA^{3}, Z=3, T=162.0 \mathrm{~K}, \mu(\mathrm{CuK \alpha})=0.513 \mathrm{~mm}^{-1}$, Dcalc $=1.114 \mathrm{~g} / \mathrm{cm}^{3}$, 46387 reflections measured $\left(5.99^{\circ} \leq 2 \theta \leq 136.916^{\circ}\right), 12355$ unique $\left(R_{\text {int }}=0.0777, R_{\text {sigma }}=0.0634\right)$ 
which were used in all calculations. The final $R_{1}$ was $0.0562(I>2 \sigma(I))$ and $w R_{2}$ was 0.1658 (all data), Flack parameter $=0.03(14)$.

\subsection{Spectroscopic Data}

Jatroidaine A (1): Colorless crystal (MeOH); mp 186-188 ${ }^{\circ} \mathrm{C}$; IR (KBr) $v_{\max }$ : 3430, 2957, 2928, 2859, 1631, 1460, 1383, 1261, 1057, $804 \mathrm{~cm}^{-1}$; UV (MeOH) $\lambda_{\max }: 203 \mathrm{~nm}$; HRESIMS m/z $411.3226[\mathrm{M}+$ $\mathrm{Na}^{+}$(calcd for $\left.\mathrm{C}_{26} \mathrm{H}_{44} \mathrm{O}_{2} \mathrm{Na}, 411.3239\right)$. ${ }^{1} \mathrm{H}-\mathrm{NMR}\left(600 \mathrm{MHz}, \mathrm{CD}_{3} \mathrm{OD}\right)$ and ${ }^{13} \mathrm{C}-\mathrm{NMR}(150 \mathrm{MHz}$, $\left.\mathrm{CD}_{3} \mathrm{OD}\right)$ data, see Table 1 .

\subsection{TrxR Inhibitory Activity Assay}

All compounds were determined for their TrxR inhibitory capacities by the previous report [11]. Briefly, the TrxR and various concentrations of test samples were mixed and incubated at room temperature in a 96-well plate. A master mixture in TE buffer containing DTNB and NADPH was added, and the absorbance at $412 \mathrm{~nm}$ was recorded during the initial $3 \mathrm{~min}$. The equivalent DMSO was used to the control experiments.

\subsection{Anti-inflammatory Assay}

The anti-inflammatory properties of compounds $\mathbf{1}-\mathbf{3}$ were evaluated by inhibition of lipopolysaccharide (LPS)-induced nitric oxide (NO) production in RAW 264.7 macrophages according to the previous literature [12]. All experiments were conducted in triplicates.

\section{Results and Discussion}

\subsection{Structure Elucidation}

Compound 1, obtained as colorless crystal in $\mathrm{MeOH}$, possessed a molecular formula of $\mathrm{C}_{26} \mathrm{H}_{44} \mathrm{O}_{2}$ by the (+)-HR-ESI-MS $\left(\mathrm{m} / z 411.3226[\mathrm{M}+\mathrm{Na}]^{+}\right.$, calcd. 411.3239), requiring five indices of hydrogen deficiency. The ${ }^{1} \mathrm{H}$ NMR spectrum (Table 1) in methanol- $d_{4}$ of 1 showed one olefinic proton at $\delta_{\mathrm{H}} 5.27$ $(1 \mathrm{H}, \mathrm{dd}, J=6.5,2.9 \mathrm{~Hz}, \mathrm{H}-7)$, one oxygenated methylene at $\delta_{\mathrm{H}} 3.54(1 \mathrm{H}, \mathrm{dt}, J=10.6,7.6 \mathrm{~Hz}, \mathrm{H}-23 \mathrm{a})$ and $3.62(1 \mathrm{H}, \mathrm{ddd}, J=10.6,8.2,4.6 \mathrm{~Hz}, \mathrm{H}-23 \mathrm{~b})$, one oxygenated methine proton at $\delta_{\mathrm{H}} 3.17(1 \mathrm{H}, \mathrm{dd}, J$ $=11.0,4.8 \mathrm{~Hz}, \mathrm{H}-3$ ), five methyl singlets at $\delta_{\mathrm{H}} 0.77,0.85,0.85,0.94,1.00$, as well as one methyl doublet at $\delta_{\mathrm{H}} 0.91(3 \mathrm{H}, \mathrm{d}, J=6.0 \mathrm{~Hz}, \mathrm{Me}-21)$. The ${ }^{13} \mathrm{C}$ NMR spectrum (Table 1) showed a total of 26 carbon signals, including one trisubstituted double bond at $\delta_{\mathrm{C}} 119.3$ (d, C-7) and 147.0 (s, C-8), one oxygenated methine carbon at $\delta_{\mathrm{C}} 79.9(\mathrm{~d}, \mathrm{C}-3)$, one oxygenated methylene at $\delta_{\mathrm{C}} 60.9(\mathrm{t}, \mathrm{C}-23)$, and six methyl carbon signals in the upfield region. The above NMR features showed high similarities to those of 24,25-epoxy-3 3,23-dihydroxy-7-tirucallene [13], a tetracyclic triterpene. Careful comparison of the NMR data of 1 with those of the tirucallane-type triterpene suggested the difference of the side-chain at $\mathrm{C}-17$ in their structures. Considering its molecular formula, this compound could be inferred to be a tetranortirucallane-type triterpenoid. This deduction was well supported by the following 2D NMR analysis: (a) the ${ }^{1} \mathrm{H},{ }^{1} \mathrm{H}-\mathrm{COSY}$ correlations (Figure 2) of $\mathrm{Me}-21 / \mathrm{H}-20 / \mathrm{H}_{2}-22 / \mathrm{H}_{2}-23$; (b) the $\mathrm{HMBC}$ correlations (Figure 2$)$ from Me-21 to C-17 $\left(\delta_{\mathrm{C}} 54.7\right)$ and C-22 $\left(\delta_{\mathrm{C}} 39.9\right)$, and from $\mathrm{H}_{2}-23$ to C-20 $\left(\delta_{\mathrm{C}}\right.$ 34.4) and C-22. The relative configuration of 1 was further verified by the following NOESY correlations (Figure 3): H-3↔H-5/Me-28, H-9↔H-5/Me-18, H-6 $\beta \leftrightarrow \mathrm{Me}-19 / \mathrm{Me}-29, \mathrm{Me}-28 \leftrightarrow \mathrm{H}-5 / \mathrm{H}-$

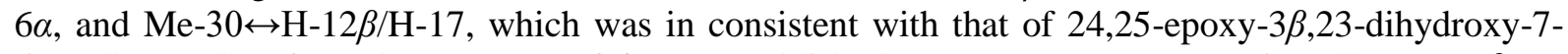
tirucallene. Therefore, the structure of $\mathbf{1}$ was established as 24,25,26,27-tetranortirucall-7-ene-3 $\beta, 23-$ diol. To our delight, the high-quality crystals were obtained in $\mathrm{MeOH}$, which allowed a successful performance of X-ray crystallography study using $\mathrm{Cu} \mathrm{K} \alpha$ radiation (Figure 4). Finally, the absolute configuration of 1 was assigned as $3 S, 5 R, 9 R, 10 R, 13 S, 14 S, 17 S, 20 S$, and named as jatroidaine A (Figure 1).

The two known compounds were identified as $3 \alpha$-hydroxy-7,24-dienetirucallic acid (2) [14] and $3 \alpha$-acetoxy-7,24-dienetirucallic acid (3) [15] by comparing their spectroscopic data with those reported in the literatures. 
Table 1. The NMR data for 1 in $\mathrm{CD}_{3} \mathrm{OD}(\delta$ in ppm, $J$ in $\mathrm{Hz})$.

\begin{tabular}{|c|c|c|}
\hline No. & ${ }^{1}$ H NMR & ${ }^{13} \mathrm{C}$ NMR \\
\hline $1 \mathrm{a}$ & $1.14(1 \mathrm{H}, \mathrm{td}, 12.6,4.6)$ & $38.6(\mathrm{t})$ \\
\hline $1 \mathrm{~b}$ & $1.69(1 \mathrm{H}, \mathrm{m})$ & - \\
\hline 2 & $1.57-1.68(2 \mathrm{H}, \mathrm{m})$ & $28.4(\mathrm{t})$ \\
\hline 3 & $3.17(1 \mathrm{H}, \mathrm{dd}, 11.0,4.8)$ & 79.9 (d) \\
\hline 4 & - & $40.0(\mathrm{~s})$ \\
\hline 5 & $1.30(1 \mathrm{H}, \mathrm{dd}, 12.0,5.7)$ & $52.2(\mathrm{~d})$ \\
\hline $6 \beta$ & $1.98(1 \mathrm{H}, \mathrm{m})$ & $25.1(\mathrm{t})$ \\
\hline $6 \alpha$ & $2.14(1 \mathrm{H}$, br d, 17.3) & - \\
\hline 7 & $5.27(1 \mathrm{H}, \mathrm{dd}, 6.5,2.9)$ & $119.3(\mathrm{~d})$ \\
\hline 8 & - & $147.0(\mathrm{~s})$ \\
\hline 9 & $2.23(1 \mathrm{H}, \mathrm{m})$ & $50.5(d)$ \\
\hline 10 & - & $36.0(\mathrm{~s})$ \\
\hline 11 & $1.49-1.61(2 \mathrm{H}, \mathrm{m})$ & $19.3(\mathrm{t})$ \\
\hline $12 \beta$ & $1.83(1 \mathrm{H}$, br dd, $13.6,9.6)$ & $35.2(\mathrm{t})$ \\
\hline $12 \alpha$ & $1.66(1 \mathrm{H}, \mathrm{m})$ & - \\
\hline 13 & - & $44.8(\mathrm{~s})$ \\
\hline 14 & - & $52.4(\mathrm{~s})$ \\
\hline $15 \mathrm{a}$ & $1.46(1 \mathrm{H}, \mathrm{ddd}, 12.1,9.5,2.2)$ & $35.1(\mathrm{t})$ \\
\hline $15 b$ & $1.54(1 \mathrm{H}, \mathrm{m})$ & - \\
\hline $16 \mathrm{a}$ & $1.33(1 \mathrm{H}, \mathrm{m})$ & $29.3(\mathrm{t})$ \\
\hline $16 b$ & $1.99(1 \mathrm{H}, \mathrm{m})$ & - \\
\hline 17 & $1.52(1 \mathrm{H}, \mathrm{m})$ & $54.7(d)$ \\
\hline 18 & $0.85(3 \mathrm{H}, \mathrm{s})$ & $22.4(q)$ \\
\hline 19 & $0.77(3 \mathrm{H}, \mathrm{s})$ & $13.6(q)$ \\
\hline 20 & $1.53(1 \mathrm{H}, \mathrm{m})$ & $34.4(d)$ \\
\hline 21 & $0.91(3 \mathrm{H}, \mathrm{d}, 6.0)$ & $19.0(q)$ \\
\hline $22 \mathrm{a}$ & $1.19(1 \mathrm{H}, \mathrm{m})$ & $39.9(\mathrm{t})$ \\
\hline $22 b$ & $1.74(1 \mathrm{H}, \mathrm{m})$ & - \\
\hline $23 a$ & $3.54(1 \mathrm{H}, \mathrm{dt}, 10.6,7.6)$ & $60.9(\mathrm{t})$ \\
\hline $23 b$ & $3.62(1 \mathrm{H}, \mathrm{ddd}, 10.6,8.2,4.6)$ & - \\
\hline 28 & $0.94(3 \mathrm{H}, \mathrm{s})$ & $28.3(q)$ \\
\hline 29 & $0.85(3 \mathrm{H}, \mathrm{s})$ & $15.4(q)$ \\
\hline 30 & $1.00(3 \mathrm{H}, \mathrm{s})$ & $27.8(\mathrm{q})$ \\
\hline
\end{tabular}

Data were measured at $600 \mathrm{MHz}$. Assignments were based on DEPT, HSQC, ${ }^{1} \mathrm{H}-{ }^{1} \mathrm{H}$ COSY, and HMBC experiments.

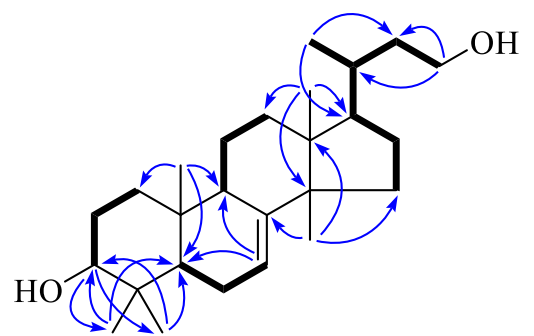

Figure 2. Key HMBC (arrows) and ${ }^{1} \mathrm{H}^{-1} \mathrm{H}^{-} \mathrm{COSY}$ (bold) correlations of compound $\mathbf{1}$

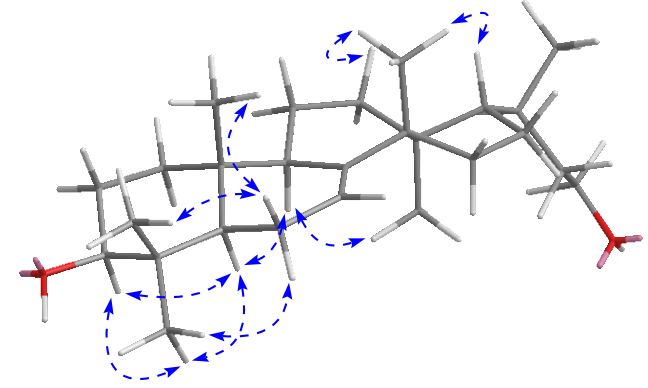

Figure 3. Key NOESY correlations of compound 1 


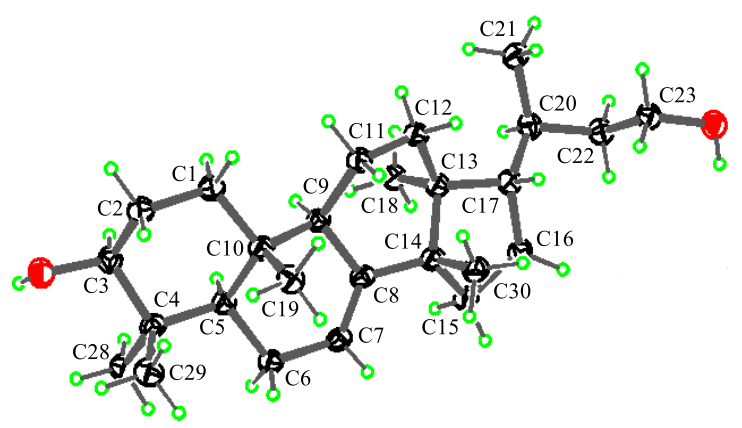

Figure 4. ORTEP drawings of compound 1

\subsection{Activity Assays}

The anti-inflammatory and TrxR inhibitory effects of isolates $\mathbf{1}-\mathbf{3}$ were evaluated. Nevertheless, no significant activity was observed.

\section{Acknowledgments}

This work was financially supported by the Program for the National Natural Science Foundation of China (81703392), the Key Research and Development Program of Shaanxi Province (No. 2020SF052), and the Natural Science Foundation of Shaanxi Provincial Department of Education (No. 20JK0595).

\section{Supporting Information}

Supporting information accompanies this paper on http://www.acgpubs.org/journal/records-ofnatural-products

\section{ORCID}

Fei Li: 0000-0002-3949-5966

Liang, Ma: 0000-0003-2282-4257

Jinyuan Zhang: 0000-0001-8566-3556

Xueling, Qiao: 0000-0001-5537-9714

Dingshan, Zhang: 0000-0001-9740-7787

Dongbo Zhang: 0000-0002-5108-9514

\section{References}

[1] J. S. Zhang, Y. Zhang, S. Li, A. Ahmed, G. H. Tang and S. Yin (2018). Cytotoxic macrocyclic diterpenoids from Jatropha multifida, Bioorg. Chem. 80, 511-518.

[2] B. Dehgan (1982). Novel Jatrophas for Florida landscapes, Proc. Fla. State Hort. Soc. 95, 277-280.

[3] O. O. Aiyelaagbe (2001). Antibacterial activity of Jatropha multifida roots, Fitoterapia 72, 544-546.

[4] J. Kayode and M. A. Omotoyinbo (2009). Ethnobotanical utilization and conservation of chewing sticks plants species in Ekiti state, Nigeria, Res. J. Bot. 3, 107-115.

[5] S. Rampadarath, D. Puchooa and V. M. Ranghoo-Sanmukhiya (2014). Antimicrobial, phytochemical and larvicidal properties of Jatropha multifida Linn, Asian. Pac. J. Trop. Med. 7, S380-S383.

[6] A. Falodun, V. Imieje, O. Erharuyi, A. Joy, P. Langer, M. Jacob, S. Khan, M. Abaldry and M. Hamann (2014). Isolation of antileishmanial, antimalarial and antimicrobial metabolites from Jatropha multifida, Asian. Pac. J. Trop. Biomed. 4, 374-378.

[7] R. Chokchaisiri, J. Srijun, W. Chaichompoo, S. Cheenpracha, L. Ganranoo and A. Suksamrarn (2020). Anti-herpes simplex type-1 (HSV-1) activity from the roots of Jatropha multifida L, Med. Chem. Res. 29, 328-333.

[8] J. Y. Zhu, C. Y. Zhang, J. J. Dai, K. Rahman and H. Zhang (2017). Diterpenoids with thioredoxin reductase inhibitory activities from Jatropha multifida, Nat. Prod. Res. 31, 2753-2758. 
[9] D. B. Zhang, Z. Wang, Y. N. Liang, J. G. Yu, Z. Zhang, S. J. Liu, Z. Zhang, Z. X. Song, Z. S. Tang and D. Z. Duan (2020). Jatrophainolides A-C, new cembrane-type diterpenoids with PTP1B inhibitory activity from the root bark of Jatropha integerrima, Phytochem. Lett. 36, 166-170.

[10] D. B. Zhang, J. G. Yu, Z. Zhang, Y. N. Liang, Z. S. Tang and Z. Wang (2020). Structure, absolute configuration and biological evaluation of a new labdane diterpenoid from Jatropha podagrica, Rec. Nat. Prod. 14, 355-360.

[11] D. Z. Duan, B. X. Zhang, J. Yao, Y. P. Liu, J. Y. Sun, C. P. Ge, S. J. Peng and J. G. Fang (2014). Gambogic acid induces apoptosis in hepatocellular carcinoma SMMC-7721 cells by targeting cytosolic thioredoxin reductase, Free Radic. Biol. Med. 69, 15-25.

[12] Z. H. Wang, H. J. Xu, Y. Y. Zhai, L. P. Yang, Q. Li, M. Huang, X. Y. Chen, W. K. Zhang, Y. L. Meng, Q. L. Zhang, C. Niu and Y. R. Zhang (2019). Three new labdane-type diterpenoids from Callicarpa macrophylla Vahl, Nat. Prod. Res. 33, 2904-2910.

[13] X. D. Luo, S. H. Wu, Y. B. Ma and D. G. Wu (2000). Tirucallane triterpenoids from Dysoxylum hainanense, Phytochemistry 54, 801-805.

[14] A. J. Mora, G. Delagdo, G. D. de Delgado, A. Usubillaga, N. Khouri and A. Bahsas (2001). 3Hydroxytirucalla-7,24-dien-21-oic acid: a triterpene from protium crenatum sandwith, Acta Cryst. C57, 638-640.

[15] M. Sawadogo, A. M. Vidal-Tessier and P. Delaveau (1985). Oleoresin of Canarium schweinfurthii Engl, Ann. Pharm. Fr. 43, 89-96.

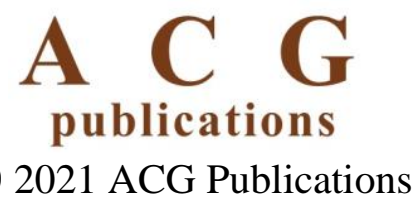

